\title{
EXPANSION OF CYLINDRICAL TUBULAR WORKPIECES ON HIGH-VOLTAGE MAGNETIC-PULSE INSTALLATION WITH CONTROLLED VACUUM DISCHARGER
}

Purpose. An experimental verification of the existence of a range of values for the parameters of the capacitive energy storage of the magnetic-pulse installations with controlled vacuum discharger, in which, with a high probability, there is a "cut» of the discharge current pulses and the expansion of cylindrical thin-walled tubular workpieces using an external coil. Methodology. High voltage magnetic-pulse installation of NTU «KhPI» with controlled vacuum discharger, multiturn coil with inside dielectrical die and inside aluminum alloy workpiece are used. The capacitance and charge voltage of capacitive energy storage are changed. Discharge current pulses are measured by Rogowski coil and the oscillograph. Results. Parts of complicated shape are made by expansion of cylindrical tubular workpieces with help of external coil. Pressed metallic tubular part is removable from inner dielectric rod. Originality. The frequency of «cut» pulse is defined by negative magnetic field pressure amplitude. It is shown that we must coordinate this frequency and charge voltage with capacitive storage parameters by high probability of pulse "cut». Practical value. It is shown how to use installations with controlled vacuum dischargers in magnetic forming technology based on «cut» pulses. References 17, tables 2, figures 5.

Key words: high-voltage magnetic-pulse installations, capacitive energy storage, controlled vacuum discharger, current pulse «cut», probability of «cut», external coil, expansion of cylindrical tubular workpiece, part of complicated shape.

Мета. Метою роботи є експериментальна перевірка існування зони параметрів ємнісного нагромаджувача енергії магнітно-імпульсної устатковини з керованим вакуумним розрядником, в котрій з високою імовірністю відбувається «зріз» імпульсів розрядного струму та розширення циліндричних тонких трубчастих заготівок за допомогою зовнішнього індуктора. Методика. Використано високовольтну магнітно-імпульсну устатковину НТУ «ХПI» 3 керованим вакуумним розрядником та багатовитковий індуктор, усередині котрого було розміщено діелектричну матрицю $і$ заготівку з алюмінієвого стопу. Змінювали ємність та зарядну напругу нагромаджувача енергіі. Імпульси розрядного струму вимірювали за допомогою поясу Роговського та реєстрували осиилографом. Результати. Магнітноімпульсним розширенням ииліндричних заготівок за допомогою зовнішнього індуктора отримано деталі складної форми та здійснено зняття металевої деталі, щүо була напресована на діелектричний стрижень. Наукова новизна. Показано, щзо частоту імпульсу, щзо «зрізається», при котрій амплітуда від'ємного тиску магнітного поля наближсається до максимальної, а також зарядну напругу необхідно узгоджувати з параметрами ємнісного нагромаджувача енергії, при яких з високою імовірністю відбувається «зріз» імпульсу. Практичне значення. Результати та рекомендації, що отримано, можуть бути використано у магнітно-імпульсних технологіях на устатковинах з керованими вакуумними розрядниками. Бібл. 17 , табл. 2 , рис. 5.

Ключові слова: високовольтна магнітно-імпульсна устатковина, ємнісний нагромаджувач енергії, керований вакуумний розрядник, «зріз» імпульсу струму, імовірність «зрізу», зовнішній індуктор, розширення циліндричної трубчатої заготівки, деталь складної форми.

Цель. Целью работь является экспериментальная проверка существования области значений параметров емкостного накопителя энергии магнитно-импульсной установки с управляемым вакуумным разрядником, в которой с высокой вероятностью происходит «срез» импульсов разрядного тока и расширение иилиндрических тонкостенных трубчатых заготовок при помощи внешнего индуктора. Методика. Эксперименты были проведены на высоковольтной магнитноимпульсной установке НТУ «ХПИ», оснащенной управляемым вакуумным разрядником. Использовали многовитковый индуктор, внутрь которого помещалась диэлектрическая матрица и заготовка из алюминиевого сплава. Изменяли емкость и зарядное напряжение накопителя энергии. Импульсы разрядного тока измеряли при помощи пояса Роговского и регистрировали на осииллографе. Результаты. Магнитно-импульсным растирением иилиндрических заготовок при помощи внешнего индуктора получены детали сложной формы и осуществлено снятие металлической детали, напрессованной на диэлектрический стержень. Научная новизна. Показано, что частоту «срезаемого» импульса, при которой амплитуда отрииательного давления магнитного поля близка к максимальной, а также зарядное напряжение необходимо согласовывать с параметрами емкостного накопителя энергии, при которых с высокой вероятностью происходит «срез» импульса. Практическое значение. Получены рекомендачии для использования в магнитно-импульсных технологиях, основанных на применении «срезанных» импульсов, установок с управляемыми вакуумными разрядниками. Библ. 17, табл. 2, рис. 5.

Ключевые слова: высоковольтная магнитно-импульсная установка, емкостной накопитель энергии, управляемый вакуумный разрядник, «срез» импульса тока, вероятность «среза», внешний индуктор, расширение цилиндрической трубчатой заготовки, деталь сложной формы.

Introduction. When performing various technological operations on magnetic-pulse installations (MPIs), workpieces in the form of thin-walled cylindrical pipes made of highly conductive metals are used [1-8]. Below, we restrict ourselves to operations based on the expansion of cylindrical workpieces of small diameter, as

well as ones inaccessible from the inside. In such cases, the use of an internal coil is difficult or impossible.

In 1965, H. Furth received a patent for devices that allows magnetic-pulse processing of cylindrical and flatsheet workpieces by the forces of attraction to the coil [9].

(C) L.A. Ljutenko, V.M. Mikhailov 
The principle of operation of these devices is based on a controlled «cut» of current pulses in the discharge circuit of a capacitive energy storage (CES). In this case, eddy currents are induced in the workpiece, causing it to be attracted to the coil. For the «cut» it is proposed to use a fusible element or an additional capacitive storage, and to enhance the effect - an additional conductor. The «cut» of the current pulses allows the cylindrical workpieces to be expanded by the magnetic field of an external coil. In one of the first works [10], the authors registered the expansion of the workpiece using an external coil. In this case, both the oscillatory and the aperiodic discharge of the CES were used [10, Fig. 4], and compression of the workpiece was prevented by an inner cylindrical mandrel. In the works of recent years, the use of a system of two coils has been proposed, through which various current pulses are passed [6], as well as the effect of two pulses of different durations, passed through one coil [7].

When using in the MPI for switching the CES of controlled vacuum dischargers (CVD), there is a natural (without additional devices [9]) «cut» of the oscillatory pulses of the discharge current (Fig. 1,a) [11, 12]. In the experiments that were carried out at NTU «KhPI» [12], attention was drawn out to the probabilistic nature of the appearance of «cut» pulses under the same conditions. In the case of a «cut» of the pulse, the negative half-wave of pressure of the magnetic field expands the workpiece 1 (pos. 1 in Fig. 1,c), and at full (not «cut») pulse (Fig. 1,b) after that it is compressed (pos. 2 in Fig. 1,c). Therefore, the determination of the parameters of the CES, at which the CVD with a high probability «cuts» discharge current pulses is an urgent problem. Some of the first results of our studies of this phenomenon and the corresponding recommendations for obtaining «cut» pulses were presented in [13].

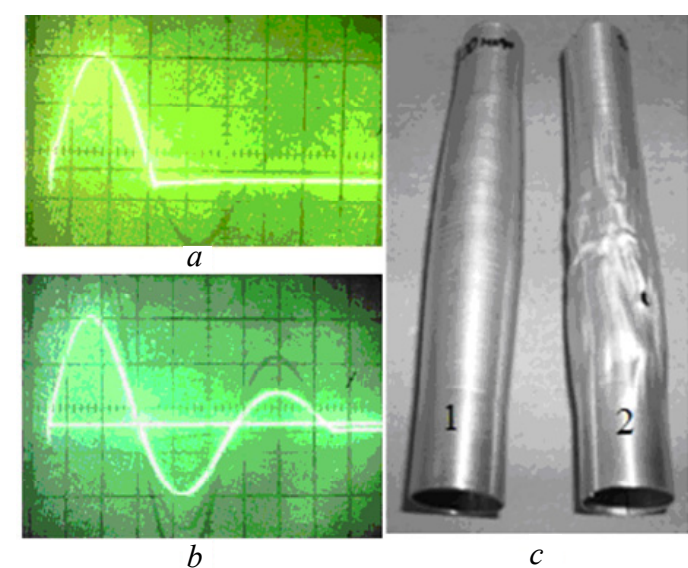

Fig. 1. «Cut» $(a)$ and full $(b)$ discharge current pulses $(50 \mu \mathrm{s} / \mathrm{div})$, as well as workpieces 1 and 2 , respectively (c), deformed by them

On the other hand, the parameters of the «cut» pulse significantly affect the amplitude of the negative halfwave of the magnetic field pressure, which expands the workpiece [14-16]. The coordination of the parameters of this pulse with the characteristics of the material and the dimensions of the workpiece has not been sufficiently studied, and the probabilistic nature of the «cut» was not taken into account.

The purpose of this work is an experimental verification of the existence of a range of values for the parameters of the capacitive energy storage of the magnetic-pulse installations with controlled vacuum discharger, in which, with a high probability, there is a «cut» of the discharge current pulses and the expansion of cylindrical thin-walled tubular workpieces using an external coil.

Equipment used in experiments. The CES of the MPI designed at NTU «KhPI» consisted of capacitors IK6-150 and allowed to change the capacitance $C=600-1200 \mu \mathrm{F}$. The CES charging voltage $U_{0}=1,5-6 \mathrm{kV}$. The CES was discharged to the coil (Fig. 2) through the RVU-63-20-UHL4 type CVD produced by the Minusinsk Electrotechnical Institute. The winding of the coil 1, which has the shape of a cylindrical spiral made of a copper bus, was connected to the MPI using leads 2 and contact nodes 3 . The position of the processed metal workpiece 4 inside the coil was fixed by a dielectric die 5 and a dielectric rod 6 , which also prevents compression of the workpiece. Tubular cylindrical billets of AMg2M aluminum alloy with specific electrical conductivity $\gamma=0.27 \cdot 10^{8} \mathrm{~S} / \mathrm{m}$ had an inner radius $R=8 \mathrm{~mm}$ and a thickness $d=0.5 \mathrm{~mm}$.

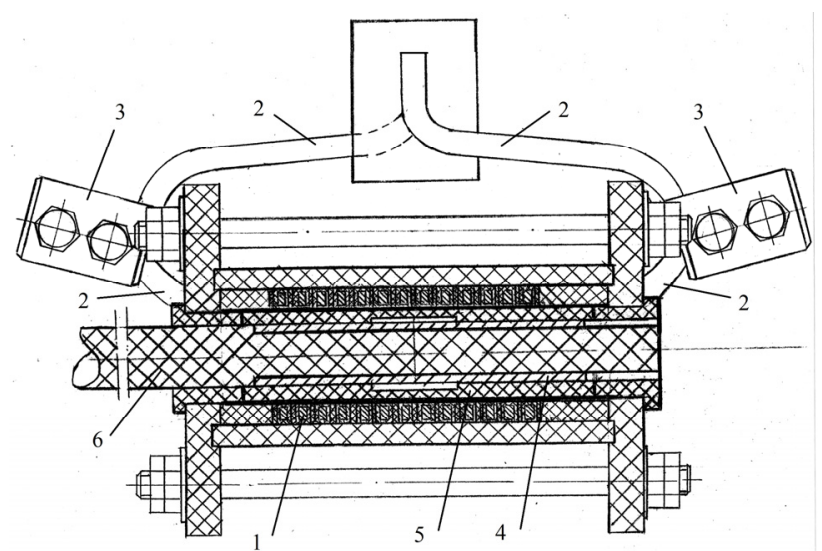

Fig. 2. Coil for magnetic-pulse expansion of cylindrical tubular workpieces

The discharge current pulses were measured using a Rogowski coil with an $R C$ integrator and recorded on an S8-13 oscilloscope. The total current pulses had a shape close to an exponentially decaying sinusoid (Fig. 1,b).

CES parameters providing a high probability of current pulses «cut». To determine $C, U_{0}$, at which there is a «cut» of the discharge current pulses, instead of die 5 (Fig. 2) a dielectric sleeve was used to prevent expansion of the workpiece. The probability of the appearance of «cut» pulses was characterized by the probabilistic frequency $N_{\mathrm{c}} / N\left(N_{\mathrm{c}}\right.$ is the number of «cut» pulses, $N$ is the total number of pulses). Table 1 shows more detailed than in work [13], the results of tests of the CVD $\left(I_{\mathrm{m} 1}\right.$ is the amplitude value of the current). After that these data were used to determine the parameters of the CES when performing technological operations. 
Table 1

Amplitude values and probabilistic frequency of the «cut» of the discharge current pulses

\begin{tabular}{|c|c|c|c|c|c|c|c|c|c|c|c|c|}
\hline \multirow{2}{*}{$U_{0}, \mathrm{kV}$} & \multicolumn{10}{|c|}{$C, \mu \mathrm{F}$} \\
\cline { 2 - 15 } & \multicolumn{3}{|c|}{600} & \multicolumn{3}{|c|}{750} & \multicolumn{3}{|c|}{900} & \multicolumn{3}{|c|}{1200} \\
\cline { 2 - 14 } & $\begin{array}{c}I_{\mathrm{m} 1}, \\
\mathrm{kA}\end{array}$ & $N$ & $N_{\mathrm{c}} / N$ & $\begin{array}{c}I_{\mathrm{m} 1}, \\
\mathrm{kA}\end{array}$ & $N$ & $N_{\mathrm{c}} / N$ & $\begin{array}{c}I_{\mathrm{m} 1}, \\
\mathrm{kA}\end{array}$ & $N$ & $N_{\mathrm{c}} / N$ & $\begin{array}{c}I_{\mathrm{m} 1}, \\
\mathrm{kA}\end{array}$ & $N$ & $N_{\mathrm{c}} / N$ \\
\hline 1,5 & 18 & 6 & 1 & 21 & 7 & 1 & 25 & 6 & 1 & 30 & 6 & 1 \\
\hline 2 & 24 & 6 & 1 & 28 & 6 & 1 & 32 & 6 & 1 & 36 & 6 & 1 \\
\hline 2,34 & 29 & 7 & 1 & 32 & 6 & 1 & 38 & 6 & 1 & 42 & 6 & 1 \\
\hline 2,7 & 32 & 18 & 0,94 & 37 & 6 & 1 & 43 & 6 & 0,83 & 50 & 6 & 1 \\
\hline 3,4 & 42 & 30 & 0,8 & 46 & 6 & 0,83 & 50 & 6 & 0,83 & 56 & 6 & 0,5 \\
\hline 3,8 & 47 & 32 & 0,8 & 51 & 6 & 0,83 & 54 & 6 & 0,83 & 62 & 6 & 0 \\
\hline 4,25 & 52 & 27 & 0,78 & 57 & 12 & 0,5 & 60 & 6 & 0,5 & 67 & 6 & 0 \\
\hline 4,65 & 57 & 10 & 0,2 & 61 & 6 & 0 & 64 & 8 & 0 & - & - & - \\
\hline
\end{tabular}

Determination of the frequency of the «cut» pulse of the discharge current. The frequency of the «cut» pulse, which can be provided by the MPI, must be matched with the electrophysical characteristics and dimensions of the workpiece. For this we use the generalized similarity criterion $\tau^{*}=\omega \cdot \tau[15]$, where $\omega$ is the circular frequency, $\tau$ is the time constant of the first approximation, $\tau=\mu_{0} \cdot \gamma \cdot R \cdot d / 2, \mu_{0}$ is the magnetic constant. The generalized criterion $\tau^{*}$ comprehensively takes into account the electrophysical characteristics $\left(\mu_{0}, \gamma\right)$ and dimensions $(R, d)$ of a thin workpiece, and also replaces two criterions $d^{*}=d / \Delta$ and $d_{R}{ }^{*}=d / R$ ( $\Delta$ is the penetration depth of the electromagnetic field [17]). In a wide range of values of the damping coefficient of an exponentially damped sinusoid, the optimal value of the generalized criterion $\tau^{*}$, at which the amplitude of the negative pressure $P_{\mathrm{m} 2}$, acting on the workpiece, is maximum, is $\tau_{0}{ }^{*}=0,8$. Here, in the range

$$
0,5 \leq \tau^{*} \leq 1,4
$$

the value of $P_{\mathrm{m} 2}$ changes insignificantly [15, Fig. 4, curves 5-8].

Condition (1) is universal and is valid for thin cylindrical workpieces made of non-magnetic materials. For the workpieces used in the experiments described here $(\tau=67,858 \mu \mathrm{s})$, from condition (1) we obtain the corresponding ranges of the recommended values of $\omega$ $(1 / \mathrm{s})$ and frequency $f(\mathrm{kHz})$ of the «cut» pulse

$$
\begin{gathered}
7368 \leq \omega \leq 20631, \\
1,173 \leq f \leq 3,284,
\end{gathered}
$$

and also the criterion $d^{*}$

$$
0,1768 \leq d^{*} \leq 0,2958 \text {. }
$$

Values $\omega, f, d^{*}$, corresponding to $\tau_{0}{ }^{*}$, equal to $\omega_{0}=117891 / \mathrm{s}, f_{0}=1,876 \mathrm{kHz}, d_{0}{ }^{*}=0,2236$.

Table 2 shows the values of the half-period duration $T / 2, \omega, f$ obtained from the oscillograms of the current in the discharge circuit of the MPI, as well as of the criteria $\tau^{*}$ and $d^{*}$

Analysis of data of Table 2, taking into account conditions (2)-(4), allows us to conclude that the MPI with a CES capacity $C=900$ or $1200 \mu \mathrm{F}$ provides the recommended frequencies of the «cut» pulse, at which the amplitude of the negative pressure of the pulsed magnetic field expanding the workpiece with the help of an external coil, is close to the maximum value.

Table 2

Time and frequency parameters of the «cut» pulses of the discharge current and the values of the criteria $\tau^{*}, d^{*}$

\begin{tabular}{|c|c|c|c|c|c|}
\hline$C, \mu \mathrm{F}$ & $\begin{array}{c}T / 2, \\
\mu \mathrm{s}\end{array}$ & $\begin{array}{c}\omega / 10^{3}, \\
1 / \mathrm{s}\end{array}$ & $f, \mathrm{kHz}$ & $\tau^{*}$ & $d^{*}$ \\
\hline 600 & 130 & 24,17 & 3,846 & 1,638 & 0,32 \\
\hline 750 & 150 & 20,94 & 3,333 & 1,44 & 0,30 \\
\hline 900 & 160 & 19,63 & 3,124 & 1,346 & 0,29 \\
\hline 1200 & 200 & 15,71 & 2,500 & 1,082 & 0,26 \\
\hline
\end{tabular}

Technological operations based on the expansion of tubular workpieces by «cut» pulses. When performing the described technological operations, it was taken $C=900 \mu \mathrm{F}, U_{0}=3.2 \mathrm{kV}$. The value of $U_{0}$ was selected experimentally from the condition of achieving sufficient deformation of the workpiece. These parameters of the CES provide both a high probability of «cut» pulses (Table 1), and the recommended frequency of the «cut» pulse (Table 2, conditions (2), (3)).

Manufacturing of parts with complex shapes. Figure 3 shows drawings of a part with one cylindrical protrusion (a) and a corresponding collapsible dielectric die $(b)$ (see also pos. 5 in Fig. 2), and Fig. 4, $a$ shows parts made from a tubular workpiece using «cut» pulses. The part can have a more complex shape, which is determined by the shape of the dielectric die, for example, it can have two cylindrical protrusions (Fig. 4,b).
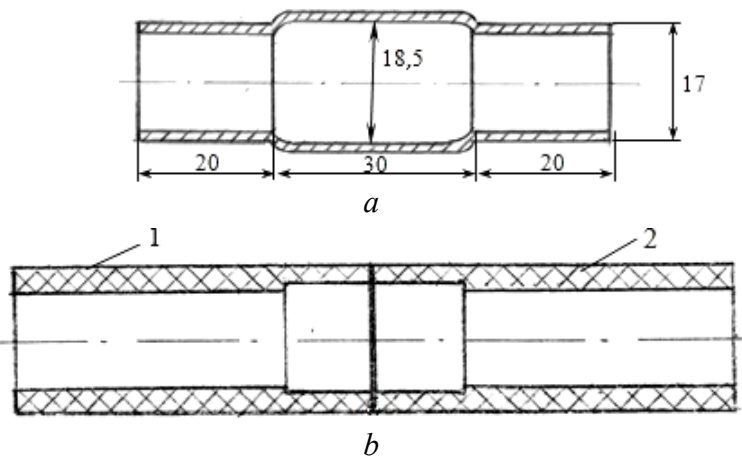

Fig. 3. Drawings of a part with one cylindrical protrusion $(a)$ and a collapsible dielectric die (b, where 1,2-symmetrical parts of the die) 


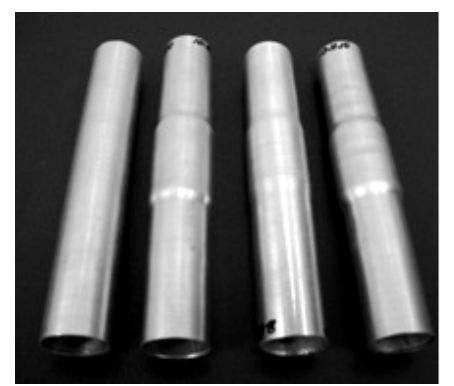

$a$

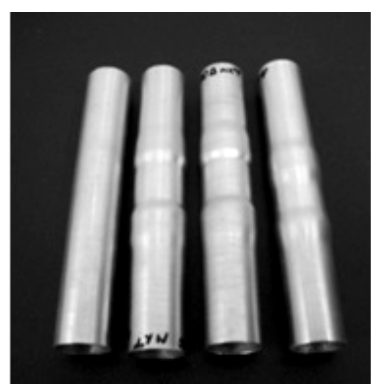

$b$
Fig. 4. Parts with one $(a)$ and two $(b)$ cylindrical protrusions, made using «cut» pulses

Removing the metal tubular part from a dielectric rod. A tubular part made of aluminum alloy was pressed onto a dielectric rod of circular cross-section using a premachined groove by magnetic-pulse compression (Fig. 5,a). To remove this part (for the purpose of replacement), a «cut» pulse of the discharge current was used, and instead of die 5 (Fig. 2) - a dielectric sleeve allowing sufficient radial expansion of the removed part ( $\sim 0.5 \mathrm{~mm})$. Figure 5,b shows workpiece 1 before pressing on the rod and parts removed in the described way $(2,3)$.

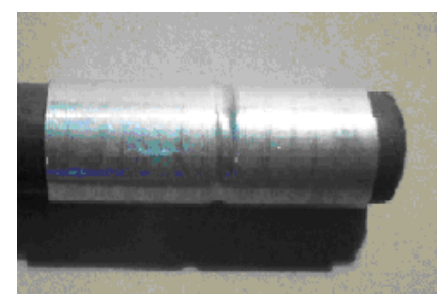

$a$

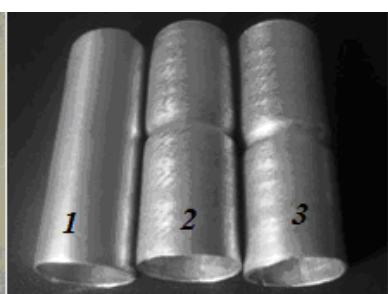

$b$
Fig. 5. Permanent joint of a dielectric rod and a tubular metal part $(a)$, a workpiece and parts removed by «cut» pulses $(b)$

The need to remove the outer technological conductive shells arises after the magnetic-pulse pressing of parts made of powder materials. If the part has a tubular shape and is accessible from the inside, then this operation can be carried out using an internal coil. The experimental results presented in this article confirm the possibility of removing the technological shell from tubular and solid cylindrical parts made of powder materials using an external coil and «cut» pulses. Note that in [16], it was noted that such an operation can be performed in the case of a cylinder made of a powder material by the second pulse of the magnetic field.

The studies carried out show that one «cut» pulse is enough: in this case, with the help of the first, positive, half-wave of pressure, the part is pressed, and with the help of the second, negative one, the technological shell is removed.

\section{Conclusions.}

1. With the help of technological operations based on the magnetic-pulse expansion of cylindrical tubular workpieces with an external coil, the existence of a range of values of the parameters of the capacitive energy storage with controlled vacuum discharger was confirmed, in which the discharge current pulses are «cut» with a high probability.

2. Before performing technological operations based on expanding workpieces using an external coil, it is necessary to test the controlled vacuum discharger and determine the values of the capacitance and charging voltage of the energy storage, at which the relative probability of the «cut» of the discharge current pulses is close to 1 .

3. The recommended frequency of the «cut « pulse of the discharge current, at which a close to optimal amplitude of negative pressure expanding the workpiece is achieved, can be determined from the conditions obtained using the generalized similarity criterion.

4. The charging voltage of the storage capacity is selected experimentally from the condition of achieving the required deformation of the workpiece and is coordinated with the test data of the controlled vacuum discharger.

5. Magnetic-pulse pressing of tubular and solid cylindrical parts made of powder materials and then removing the technological conductive shell can be carried out with one «cut» current pulse.

Conflict of interest. The authors declare that they have no conflicts of interest.

\section{REFERENCES}

1. Bely I.V., Fertik S.M., Khimenko L.T. Spravochnik po magnitno-impulsnoj obrabotke metallov [Handbook on magnetic-pulse processing of metals]. Kharkiv, Vishcha shkola Publ., 1977, 168 p. (Rus).

2. Psyk V., Risch D., Kinsey B.L., Tekkaya A.E., Kleiner M. Electromagnetic forming - A review. Journal of Materials Processing Technology, 2011, vol. 211, no. 5, pp. 787-829. doi: https://doi.org/10.1016/j.jmatprotec.2010.12.012.

3. Qiu L., Yu Y., Yang Y., Nie X., Xiao Y., Ning Y., Wang F., Cao C. Analysis of electromagnetic force and experiments in electromagnetic forming with local loading. International Journal of Applied Electromagnetics and Mechanics, 2018, vol. 57, no. 1, pp. 29-37. doi: https://doi.org/10.3233/jae-170038.

4. Zhang X., Li C., Wang X., Zhao Y., Li L. Improvement of deformation behavior of tube in electromagnetic forming with a triple-coil system. International Journal of Applied Electromagnetics and Mechanics, 2019, vol. 61, no. 2, pp. 263272. doi: https://doi.org/10.3233/jae-180122.

5. Prokofiev A.B., Beliaeva I.A., Glushchenkov V.A., Karpukhin V.F., Chernikov D.G., Iusupov R.Iu. Magnitnoimpul'snaia obrabotka materialov [Magnetic-pulse processing of materials]. Samara, SNTs Publ., 2019. 140 p, Available at: http://repo.ssau.ru/handle/Monografii/Magnitnoimpulsnayaobrabotka-materialov-MIOM-Elektronnyi-resurs-monografiya-

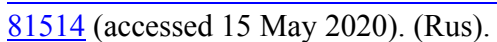

6. Li X., Cao Q., Lai Z., Ouyang S., Liu N., Li M., Han X., Li L. Bulging behavior of metallic tubes during the electromagnetic forming process in the presence of a background magnetic field. Journal of Materials Processing Technology, 2020, vol. 276, p. 116411. doi: https://doi.org/10.1016/j.jmatprotec.2019.116411. 7. Xiong Q., Yang M., Tang H., Huang H., Song X., Qiu L., Yu K., Cao Q. Flaring Forming of Small Tube Based on Electromagnetic Attraction. IEEE Access, 2020, vol. 8, pp. 104753104761. doi: https://doi.org/10.1109/access.2020.2999125.

8. Chernikov D.G., Glushchenkov V.A., Gusev D.V., Pfetzer I.A., Alyokhina V.K. Evaluation of the efficiency of the process of electromagnetic forming of small-diameter tubes. Izvestiya of Samara Scientific Center of the Russian Academy of Sciences, 2020, vol. 22, no. 4, pp. 21-28. (Rus). doi: https://doi.org/10.37313/1990-5378-2020-22-4-21-28.

9. Furth Harold P. Devices for metal-forming by magnetic tension. Patent USA no. 3,196,649, July, 27, 1965. 
10. Shcheglov B.A., Esin A.A. Distribution of thin-walled tubular workpieces by the forces of attraction of a pulsed magnetic field. Forging and Stamping Production. Material Working by Pressure, 1971, no. 4, pp. 15-17. (Rus).

11. Yusupov R.Yu. Magnetic-pulse installations of a new generation for industrial and educational-scientific purposes. Proceedings of the International Scientific and Technical Conference MIOM-2007, 2007, pp. 251-259. (Rus).

12. Bondina N.N., Konovalov O. Ya., Legeza A.V., Makeev V.G., Mikhailov V.M., Shovkoplyas A.V. Magnetic-pulse expansion of a cylindrical conducting shell and creation of a given distribution fields using an external coil. Technical electrodynamics. Thematic issue "Problems of modern electrical engineering», 2008, chapter 5, pp. 84-89. (Rus).

13. Ljutenko L.A., Mikhailov V.M. The probability of interruption current pulses in circuit of capacitor bank with vacuum discharger. Technical electrodynamics, 2012, no. 3, pp. 121-122. (Rus).

14. Ljutenko L.A., Mikhailov V.M. Influence of the shape of an external magnetic field pulse on electrodynamic forces deforming a cylindrical shell. Technical electrodynamics, 2007, no. 6, pp. 15-19. (Rus).

15. Bondina N.N., Kramchanin E.G., Ljutenko L.A., Mikhailov V.M. Electrodynamic forces acting on a cylindrical shell under oscillating discharge of a magnetic pulse forming machine. Electrical Engineering \& Electromechanics, 2007, no. 5, pp. 6670. (Rus).

16. Boltachev G.Sh., Volkov N.B., Paranin S.N., Spirin A.V. Dynamics of cylindrical conducting shells in a pulsed longitudinal magnetic field. Technical Physics, 2010, vol. 55, no. 6, pp. 753761. doi: https://doi.org/10.1134/S1063784210060010.

17. Neyman L.R., Demirchyan K.S. Teoreticheskie osnovy elektrotechniki. $V$ 2-h tomah. Tom 2 [Theoretical bases of the Electrical Engineering. In 2 vols. Vol. 2]. Leningrad, Energoizdat Publ., 1981. 416 p. (Rus).

Received 15.04.2021

Accepted 24.05.2021

Published 25.06.2021

\section{L.A. Ljutenko ${ }^{1}$,}

V.M. Mikhailov ${ }^{1}$, Doctor of Technical Science, Professor,

${ }^{1}$ National Technical University «Kharkiv Polytechnic Institute», 2, Kyrpychova Str., Kharkiv, 61002, Ukraine,

e-mail: lutenkola@gmail.com,

valery.m.mikhailov@gmail.com (Corresponding author),

How to cite this article:

Ljutenko L.A., Mikhailov V.M. Expansion of cylindrical tubular workpieces on high-voltage magnetic-pulse installation with controlled vacuum discharger. Electrical Engineering \& Electromechanics, 2021, no. 3, pp. 42-46. doi: https://doi.org/10.20998/2074-272X.2021.3.07. 